\title{
Literature Review: Dental Aspects in Gaucher Disease
}

\author{
Revisión de la Literatura: Aspectos Dentales en la Enfermedad de Gaucher \\ Elza Maria Carneiro Mendes Ferreira dos Santos; Vanessa de Araújo Faria² \& \\ Plauto Christopher Aranha Watanabe ${ }^{3}$
}

SANTOS, E. M. C. M. F.; FARIA, V. A. \& WATANABE, P. C. A. Dental aspects in Gaucher disease. Int. J. Odontostomat., 12(2):147-151, 2018.

SUMMARY: Knowledge about Gaucher disease, characteristics, clinical and radiographic alterations, demonstrate the importance of using anamnesis, laboratory tests and radiological images, among these dental analysis and images, making possible the early detection in the oral manifestations and the success in the control and treatment of the disease. disease.

KEY WORDS: Gaucher disease, neuronopathic Gaucher disease, Gaucher disease Type 1.

\section{INTRODUCTION}

Gaucher disease (GD) was first described in 1882. It is a systemic lysosomal storage disorder caused by hereditary deficiency - an autosomal recessive disorder resulting from pathogenic mutations in the gene that encodes glucocerebrosidase enzyme, resulting in an accumulation of glucocerebrosides in the phagocytes and central nervous system (CNS). The cell has the appearance of "Signature Rings with Crumpled Kleenex". The lipid stored in the lysosomes overflows into the cytoplasm, and the glycosylceramide is converted into glycosylsphingosine, with an increase in its serum levels. The production of these bioactive lipids involves other types of cells, such as the immune system, which secretes cytokines that are responsible for bone destruction and participation in the onset and spread of the pathogenesis of the disease. Pathophysiologically, Gaucher cells are characterized by distended phagocytic cells found in spleen, liver, and bone marrow, among others (Beutler et al., 1993).

In the general population, the estimated frequency is in the range of $1: 50,000$ to $1: 100,000$ (Meikle et al., 1999). Found mostly in the Ashkenazi Jewish population, with a rate of 1:17 and an expected
1:850 birth rate (Beutler et al.). Two distinct forms of the disease are also relatively more common in the northern Norrbotten region of Sweden (Svennerholm et al., 1991) and near the Palestinian city of Jenin (Abrahamov et al., 1995). Among the Ashkenazi Jews, the N370S mutations, which are associated with the milder expression of the disease is more common (Zimran \& Elstein, 2011).

Three are the described types of this disease; their differentiation in type 1 is performed with absence of neurological factor, and in types 2 and 3 in the progression rate and neurological characteristics (Table I).

Type 1 might be asymptomatic or incidentally discovered during an evaluation of a hematological disorder. With symptomatic patients, the spleen might be only palpable or mass enlarged and might produce positional symptoms, such as early satiety or abdominal discomfort. Abdominal pain is rare, but when present it might be an indication of a splenic infarction or a sub capsular hematoma. Hepatomegaly is usually asymptomatic. In most patients, liver function tests are

\footnotetext{
${ }^{1}$ Cirurgiã Dentista, Radiologista, Mestranda em ciência das Imagens e Física Médica da Faculdade de Medicina de Ribeirão Preto Universidade de São Paulo, Brazil.

${ }^{2}$ Cirurgiã Dentista-Ortodontista Mestranda em Diagnóstico Bucal pela Faculdade de Odontologia de São Paulo Universidade de São Paulo, Brazil.

${ }^{3}$ Professor da Clínica Médica da Faculdade de Medicina de Ribeirão Preto, Área de Radiologia. Professor Titular do DESCOL - Faculdade de Odontologia de Ribeirão Preto / USP, Área de radiologia odontológica e Imaginologia, Brazil.
} 
within the limits of normality, unless there is liver comorbidity such as viral or autoimmune hepatitis.

Bleeding is common and can manifest as frequent epistaxis (nose bleeding), bruising, hemorrhage after surgical or dental procedures, or may be associated with pregnancy or childbirth. Bleeding is usually secondary to thrombocytopenia resulting from hypersplenism and / or reduced platelet production, which may be caused by bone marrow infiltration by Gaucher cells. Abnormal platelet function or abnormal coagulation and / or fibrinolytic factors are also observed (Hollak et al., 1997). Fatigue is another common complaint, usually related to anemia, but not invariably. Also reduced levels of hemoglobin, mainly due to hypersplenism, but additionalcauses include iron deficiency (also secondary to bleeding), vitamin B12 deficiency, and autoimmune hemolysis. In children, linear growth retardation is common, regardless of the overall severity of the disease.

Manifestations in the jaws. There are case reports of patients with some degree of mandibular-maxillofacial involvement, frequently observed accidentally on routine dental or panoramic radiographs (Hollak et al.). The most common radiographic observation is the presence of pseudo cystic radiolucent lesions or honeycomb, welldefined lesions, especially in the premolar regions (Bender, 1938). The increase in osteopenia and the generalized rarefaction of trabecular bone are commonly observed. Other radiographic findings include osteoporosis, enlargement of bone marrow spaces, and in some cases apical root resorption, all presumably due to Gaucher cell density (Bender, 1938; Carter et al., 1998). Areas of mandibular radiopacity were presented as being due to temporary bone regeneration after extraction (Bender, 1959) or to a sclerotic reaction to the infiltration of Gaucher cells. The involvement of the jaws is similar to skeletal extra gnathic involvement, which accounts for $90 \%$ of patients, all cases involving the jaw, while only one quarter affects the maxilla. According to some authors, this is due to the fact that the mandible is considered a long bone. It is important to note that even this picture may be relatively benign and spontaneously reversed, because these "lesions" are Gaucher cells that act as "petrified" Gaucher bones.

This loss of normal trabecularization is observed in other long bones in Gaucher disease. Both the arches, maxilla and jaw can be affected by these phenomena. Apparently, the loss of corticalization of the mandibular canal, thinning of the cortical and hard lamina, obliteration of the maxillary sinus can be attributed to this process, observing other phenomena caused by the massive infiltration of Gaucher cells, which radiographically appear well-defined cells, circumscribed radiolucent lesions, similar to other cysts and tumors in the mandible. This lesion may present a soap bubble aspect (10.8\%), dislocate mandibular canal or teeth and root resorption (Zeevi et al., 2013).

Wenstrup et al. (2002) conceptualize two types of bone manifestations associated with Gaucher disease: Extra gnathic bone pathology, which breaks down into: 1. Focal disease - irreversible lesions such as osteonecrosis and osteocloserosis; 2. Local disease reversible abnormality adjacent to large marrows, such as cortical thinning and bone defects; 3. Generalized osteopenia.

Bildman et al. (1972) reported establishing the diagnosis of Gaucher disease after a biopsy of mandibular medulla tissue; others confirmed Gaucher disease based on the presence of Gaucher cells in mandible biopsies (Lustmann et al., 1991). However, it should be emphasized that jaw biopsy in Gaucher disease is not recommended unless another condition is suspected (for example, malignancy). If Gaucher disease is suspected, an enzymatic assay - and not a biopsy or a bone marrow sampling - is the appropriate medium to perform the diagnosis.

\section{MATERIAL AND METHOD}

Articles and clinical protocols and therapeutic guidelines - Ministry of Health (Ministério da Saúde, 2014), were reviewed as clinical and radiographic citations (Table II) of relevance to the quality of dental treatment.

The gold standard for the diagnosis of Gaucher disease is the detection of low levels of enzyme activity in peripheral blood cells compared to normal control samples taken on the same day. Molecular analyzes of the genotype sometimes serve as an adjuvant in assessing the potential trajectory of disease severity Zimran (2011).

For dentistry, the possibility of assisting in the early recognition of Gaucher Disease would be very interesting because of the radiographic characteristics, which are in fact confused with several other situations, such as, for example, mandibular osteoporosis, except Type 2, which affects mainly children, or other bone diseases, such as ameloblastoma. 


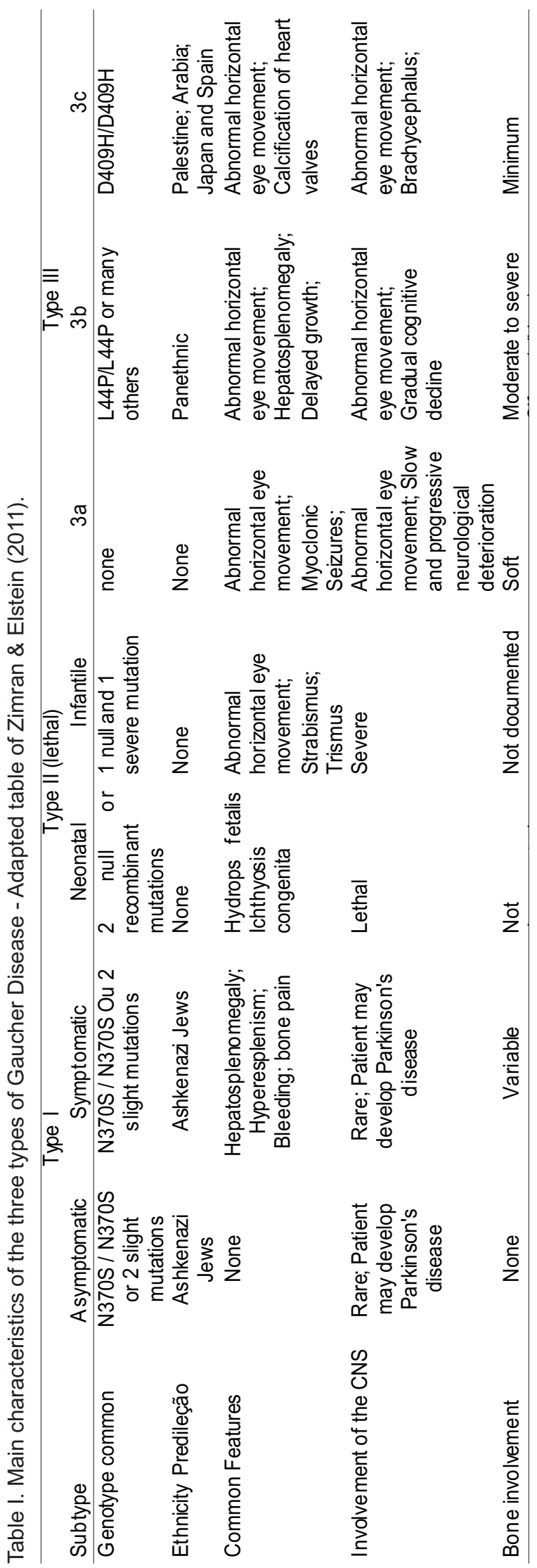

Sclerosis or erosion of the cortex occur on the endosteal surface. This finding is not specific for Gaucher disease, and it can be found in hemolytic anemias, leukemia, hyperthyroidism, former consolidated fractures, and Albers-Schonberg disease. Involvement of the jaw, skull, hands and feet is (Mendonça et al., 2001).

As shown in Table II, there are several manifestations of dental interest, which will directly interfere with the planning of the case, since many of these children / adolescents / adults are receiving dental treatment without knowledge of the disease, as well as in treatments, without the odontologist knowing these manifestations.

There is no cure for Gaucher disease. Since its approval by the US Food and Drug Administration (FDA) in 1991 (Barton et al., 1991; Zimran et al., 1995), intravenous infusions of enzyme replacement therapy (ERT) are widely used to treat symptomatic patients. In most patients, ERT induces the reduction of hepatosplenomegaly, improves hematological abnormalities and improves bone pain and bone mineral density within 5 years after the advent of therapy (Weinreb et al., 2002). Today, there are two FDA-approved ERTs that are also widely approved in Europe and other countries: Imiglucerase (Cerezyme, Genzyme Corporation, Cambridge MA, USA) and velaglucerase alfa (Vpriv, Shire HGT, Cambridge MA, USA). In the Santa Catarina study, Ferreira emphasizes the importance of the genotype study and genetic counseling, and shows effective and safe result with ERT — recombinant enzyme (Imiglucerase), in cases of type 1 Gaucher.

\section{CONCLUSION}

Careful analysis of signs and symptoms and medical history with a thorough review is very important in the assessment of patients with lysosomal storage disorders. The studies demonstrate that the investigation with laboratory exams and radiological images, among them the dental ones, can help in the early recognition of the Gaucher Disease, causing in alteration of the initial planning and consequently in the treatment plan.

The most important part of optimizing one's health with Gaucher disease is seeing a Gaucher specialist. Because the disease affects just 1 in 40,000 in the general population, many general practitioners and even specialists have never managed a patient with Gaucher disease. A specialist can help by: 
Table II. Demographic and radiological characteristics of patients with Gaucher disease involving the mandible, reported in the literature between 1982 e 2012.

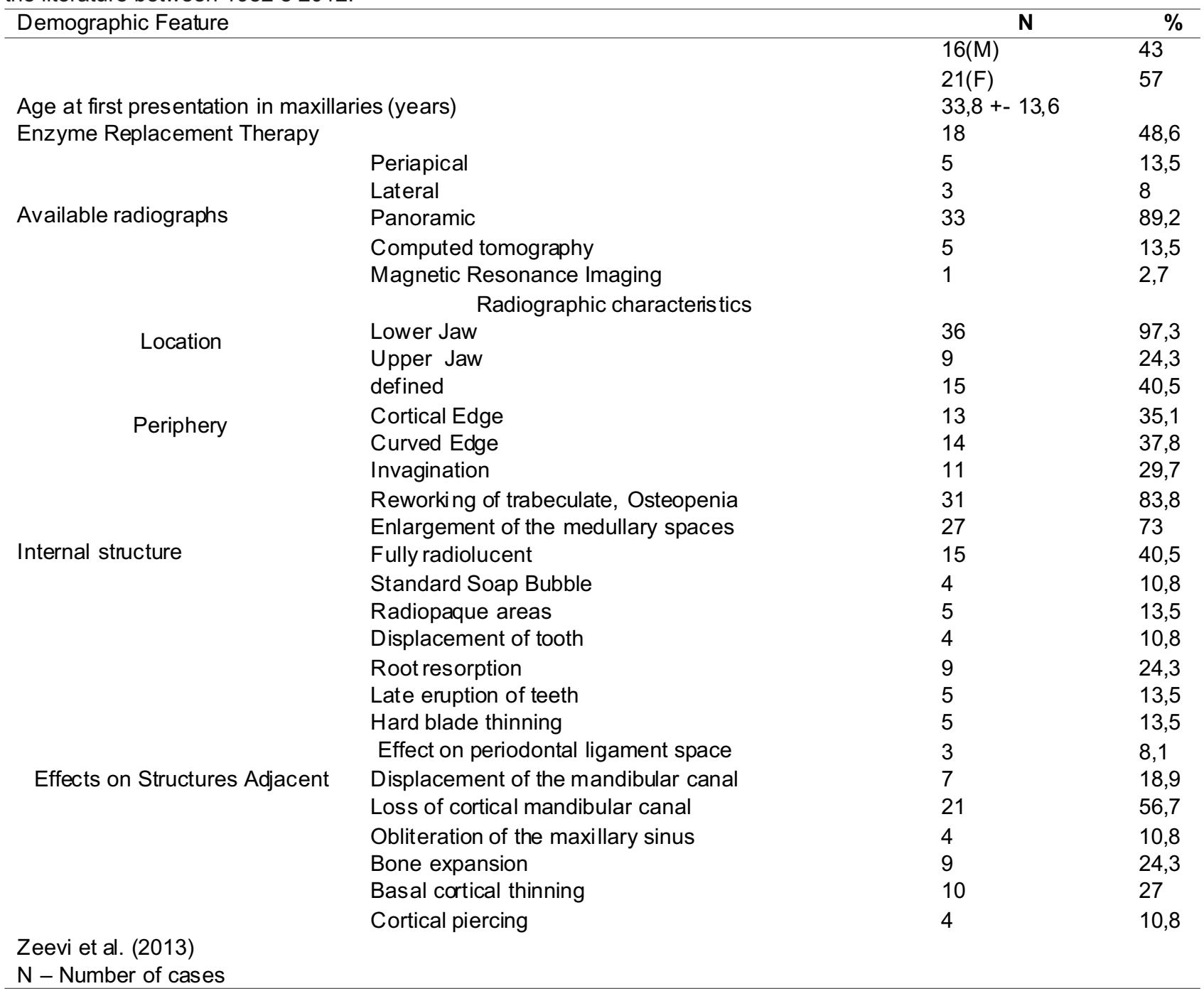

Creating a comprehensive evaluation plan to determine treatment needs and help set individualized treatment goals that are both realistic and meaningful. Managing symptoms with an individualized treatment plan. The treatment plan should include tracking key health indicators like blood counts, spleen and liver volume, bone density and health-related quality of life.

Coordinating care with a primary care physician and other specialists such as radiologists, orthopedists and pain management experts.

Proactively monitoring for conditions related to Gaucher disease.
SANTOS, E. M. C. M. F.; FARIA, V. A. \& WATANABE, P. C. A. Int. J. Odontostomat., 12(2):147-151, 2018.

RESUMEN: El conocimiento sobre la enfermedad de Gaucher, características, alteraciones clínicas y radiográficas, demuestra la importancia de utilizar la anamnesis, los exámenes de laboratorio e imágenes radiológicas, entre ellas las odontológicas, posibilitando la detección precoz de las manifestaciones orales, y el éxito en el control y tratamiento de la enfermedad.

PALABRAS CLAVE: enfermedad de gaucher, enfermedad neuropática de gaucher, enfermedad de gaucher Tipo 1. 


\section{REFERENCES}

Abrahamov, A.; Elstein, D.; Gross-Tsur, V.; Farber, B.; Glaser, Y.; Hadas-Halpern, I.; Ronen, S.; Tafakjdi, M.; Horowitz, M. \& Zimran, A. Gaucher's disease variant characterised by progressive calcification of heart valves and unique genotype. Lancet, 346(8981):1000-3, 1995.

Barton, N. W.; Brady, R. O.; Dambrosia, J. M.; Di Bisceglie, A. M.; Doppelt, S. H.; Hill, S. C.; Mankin, H. J.; Murray, G. J.; Parker, R. I. \& Argoff, C. E. Replacement therapy for inherited enzyme deficiency--macrophage-targeted glucocerebrosidase for Gaucher's disease. N. Engl. J. Med., 324(21):1464-70, 1991.

Bender, I. B. Dental observations in Gaucher's disease; a twentyyear follow-up. Oral Surg. Oral Med. Oral Pathol., 12(5):546-61, 1959.

Bender, I. B. Dental observations in Gaucher's disease. J. Dent. Res., 17(5):359-69, 1938.

Beutler, E.; Nguyen, N. J.; Henneberger, M. W.; Smolec, J. M.; McPherson, R. A.; West, C. \& Gelbart, T. Gaucher disease: gene frequencies in the Ashkenazi Jewish population. Am. J. Hum. Genet., 52(1):85-8, 1993.

Bildman, B.; Martinez, M. \& Robinson, L. H. Gaucher's disease discovered by mandibular biosy: Report of case. J. Oral Surg., 30:510-2, 1972.

Carter, L. C.; Fischman, S. L.; Mann, J.; Elstein, D.; Stabholz, A. \& Zimran, A. The nature and extent of jaw involvement in Gaucher disease: observations in a series of 28 patients. Oral Surg. Oral Med. Oral Pathol. Oral Radiol. Endod., 85(2):233-9, 1998.

Hollak, C. E.; Levi, M.; Berends, F.; Aerts, J. M. \& van Oers, M. H. Coagulation abnormalities in type 1 Gaucher disease are due to low-grade activation and can be partly restored by enzyme supplementation therapy. Br. J. Haematol., 96(3):470-6, 1997.

Lustmann, J.; Ben-Yehuda, D.; Somer, M. \& Ulmansky, M. Gaucher's disease affecting the mandible and maxilla. Report of a case. Int. J. Oral Maxillofac. Surg., 20(1):7-8, 1991.

Meikle, P. J.; Hopwood, J. J.; Clague, A. E. \& Carey, W. F. Prevalence of lysosomal storage disorders. JAMA, 281(3):249-54, 1999.

Mendonça, V. F.; Machado, P. M. T.; Fernandes, C. \& Boasquevisque, E. M. Manifestações esqueléticas da doença de gaucher. Radiol. Bras., 34(3):151-4, 2001.

Ministério da Saúde. Doença de Gaucher. Protocolos Clínicos e Diretrizes Terapêuticas. Brasília, Ministério da Saúde, 2014. pp.159. Available from: http://bvsms.saude.gov.br/bvs/ publicacoes/protocolos_clinicos_diretrizes_terapeuticas_v3.pdf

Svennerholm, L.; Erikson, A.; Groth, C. G.; Ringdén, O. \& Mānsson, J. E. Norrbottnian type of Gaucher disease--clinical, biochemical and molecular biology aspects: successful treatment with bone marrow transplantation. Dev. Neurosci., 13(4-5):345-51, 1991.

Weinreb, N. J.; Charrow, J.; Andersson, H. C.; Kaplan, P.; Kolodny, E. H.; Mistry, P.; Pastores, G.; Rosenbloom, B. E.; Scott, C. R.; Wappner, R. S. \& Zimran, A. Effectiveness of enzyme replacement therapy in 1028 patients with type 1 Gaucher disease after 2 to 5 years of treatment: a report from the Gaucher Registry. Am. J. Med., 113(2):112-9, 2002.

Wenstrup, R. J.; Roca-Espiau, M.; Weinreb, N. J. \& Bembi, B. Skeletal aspects of Gaucher disease: a review. Br. J. Radiol., 75 Suppl. 1:A2-12, 2002.

Zeevi, I.; Anavi, Y.; Kaplan, I. \& Zadik, Y. Jaws features in Type 1 Gaucher disease. J. Oral Maxillofac. Surg., 71(4):694-701, 2013.

Zimran, A. \& Elstein, D. Lipid Storage Diseases. In: Lichtman, M.; Kipps, T.; Seligsohn, U.; Kaushansky, K. \& Prchal, J. (Eds.). Williams Hematology. 8th ed. New York, McGraw-Hill Publishers, 2011. pp.1065-71.

Zimran, A. How I treat Gaucher disease. Blood, 118(6):1463-71, 2011.
Zimran, A.; Elstein, D.; Levy-Lahad, E.; Zevin, S.; Hadas-Halpern, I.; Bar-Ziv, Y.; Foldes, J.; Schwartz, A. J. \& Abrahamov, A. Replacement therapy with imiglucerase for type 1 Gaucher's disease. Lancet, 345(8963):1479-80, 1995.

\author{
Corresponding author: \\ Elza Maria Carneiro Mendes Ferreira dos Santos \\ Universidade de São Paulo. \\ Rua Joaquim Mourão, 353 - $2^{\circ}$ andar - sala 02 - \\ Centro Leme SP. \\ Cep 13.610-070 \\ São Paulo \\ BRAZIL
}

Email: santoselzacarneiro@gmail.com

Received: 16-10-2017

Accepted: 22-02-2018 